\title{
Contagion between Islamic and Conventional Banks in Malaysia: Empirical Investigation using a DCC-GARCH Model
}

\author{
Monia Ben Latifa \\ Faculty of Economic Sciences and Management of Sfax, \\ Department of Finance, University of Sfax, Tunisia \\ Walid Khoufi \\ Faculty of Economic Sciences and Management of Sfax, \\ Department of Finance, University of Sfax, Tunisia
}

\begin{abstract}
The purpose of this paper is to compare the stability, in terms of contagion, of conventional and Islamic banks in Malaysia. We use a DCC-GARCH model to estimate the dynamic conditional correlation (a measure of financial contagion) for a sample of one Islamic bank and eight conventional banks during the period from March 31, 2004 to March 18, 2014. From the empirical findings, we show that the conditional correlation between the returns of conventional and Islamic banks in Malaysia increased during the period of financial crisis. This finding implies the existence of a financial contagion effect between Islamic and conventional banks in Malaysia. Also, we find that financial contagion represents a major factor for the transmission of risk between Islamic and conventional banks.
\end{abstract}

Keywords: contagion, Islamic banks, conventional banks, DCC-GARCH, Malaysia.

JEL Classification: Q9, Q91.

KAUJIE Classification: E3, H2, I2. 


\section{Introduction}

Since 2007, the world has experienced a severe financial crisis. The crisis had its roots in the US market and then spread to the entire world. This crisis affectted real economic activities and the overall global economic climate. However, Islamic banking has emerged as a stable alternative to conventional banking over this period according to some studies (Cihak \& Hesse, 2008; Hasan \& Dridi, 2010). On the other hand, other researchers show that Islamic banks have been hit by the crisis because they are exposed to the same risks since Islamic banks are part of the financial sector (Bourkhis \& Nabi, 2013; Boumediene \& Caby, 2013; Fakhfekh \& Hachicha, 2014).

The spread of the crisis is explained by two factors, the first phenomenon is the direct exposure of financial institutions around the world to the US crisis. The second factor explaining its spread is that of increased contagion between markets.

There are numerous studies which investigate the existence of contagion consequence of different crises on diverse equity markets. Many methodologies have been used to assess how shocks are transmitted internationally: cross-market correlation coefficients, Auto Regressive Conditional Heteroskedasticity (ARCH) and General Auto-Regressive Conditional Heteroskedasticity (GARCH) models, cointegration techniques, and direct estimation of specific transmission mechanisms. The initial empirical literature on financial contagion undertook comparative studies using Pearson's correlation coefficients among markets in calm and in crisis periods. Contagion was found when significant correlations occurred in periods of crisis.

King and Wadhwani (1990), and Lee and Kim (1993) employ the correlation coefficient among stock returns to test for the effect of the US stock crash in 1987 on the equity markets of numerous countries. However, studying the contagious effect of the global financial crisis on MENA stock markets was not common in the literature despite their importance for international diversification. Malaysia which has recently become more integrated into the world economy, was also severely impacted by the global financial crisis. In this context, it is important to examine the financial contagion in this country especially the dynamic dependence of Islamic and conventional banks.
The analysis of the stability of Islamic banks relative to conventional banks becomes more relevant when the analysis period includes the recent global financial crisis. Indeed, the crisis induced a series of failures of many conventional banks and constitutes a good test of the stability of Islamic banks. From a theoretical perspective, the Profit and Loss Sharing (PLS) principle enables Islamic banks to maintain their net worth under difficult economic situations. Indeed, any shock that could generate losses on their asset side will be absorbed on the liability side (Nabi, 2012).

The governor of the Malaysian central bank (Aziz, 2008), asserted in a speech the protection from risk that an Islamic bank has as a result of its business model features. However, Betz, Oprică, Peltonen, \& Sarlin, (2014) found that a strong connection to the real economy will increase the systemic exposure to contagious effects, which challenges the stability of Islamic banks in a novel way due to its strong connection to the real economy.

In this context, we investigate empirically in this paper the financial contagion between Islamic and conventional banks in Malaysia. Then, we employ the DCC-GARCH model to estimate the conditional dynamic correlation which quantifies financial contagion. We employ a sample composed of one Islamic bank and eight conventional banks during the period of study from March 31, 2004 to March 18, 2014.

The empirical results suggest that the correlation among the returns of the two types of banks in Malaysia increased in the post-crisis period compared to the pre-crisis. This finding implies the existence of a contagion effect between Islamic and conventional banks in Malaysia. Also, it implies that financial contagion represents a major source for the spread of the crisis between Islamic and conventional banks in Malaysia.

The rest of our paper is organized as follows. In section 2 we present a literature review concerning the measurement of financial contagion. Section 3 is devoted to the econometric methodology used to test the existence of financial contagion. In section 4 we present the data used in this paper. The empirical results are discussed in section 5 while section 6 concludes. 


\section{Literature Review}

Indeed, there are different ways to measure financial contagion. In this regard, Hamao, Masulis, and Ng (1990) conduct their studies on the stock exchanges of New York, London and Tokyo. They use an ARCH model. They analyze the volatility of stock prices in each market and possible transmission from one market to another. The results show that there are effects of volatility transmission from New York to Tokyo and prices from London to Tokyo, but not from Tokyo to New York or London.

Moreover, Tai (2004) applies the MGARCH approach to estimate the conditional mean stock returns and volatility during various periods of instability. In addition, to test for the existence of a contagion, he uses the BEKK model developed by Baba, Engle, Kraft, and Kroner (1991). The results show that on average, the contagion effects tend to be multidirectional. Based on the dependence between the banking market, the stock market, and the money market, he examines the impact of contagion on volatilities of these markets. He finds that this contagion has a negative impact upon the volatilities of the banking sector only. This empirical result shows that the impact on volatility and returns can be contagious, suggesting that banks may represent an important source of contagion during volatile periods.

Eichengreen, Rose, and Wyplosz (1996) study the propagation of crises in 20 countries over 1959-1993. They pro-pose a probit model linking a dependent variable of macroeconomic variables and contagion variables. This test assesses the likelihood of the realization of a crisis in both countries at the same time. They show that speculative attacks on the foreign currency affect the probability of speculative attacks on the local currency. But that does not identify the type of trade transmission channel or common shocks.

Bekaert and Harvey (1997) study stock market contagion in twenty emerging countries. They use the GARCH (Generalized Autoregressive Conditional Heteroskedasticity) multivariate model. They employ macroeconomic variables to measure the degree of integration of each country (share of international trade on GDP). According to their results, the more integrated a country is the more exposed it is to a strong shock from the outside by the transmission channels.
In addition, $\mathrm{Ng}$ (2000) studies a contagion effect flowing from the markets of America and Japan to the Pacific-Basin with a Generalized Autoregressive Conditional Heteroskedasticity (GARCH) multivariate model. She uses weekly data of returns of the stock market based in countries of the Pacific-Basin and the US and Japanese indices. The results show that there is a transmission of volatility from the Japanese and US markets to Malaysia, Singapore, Taiwan and Thailand and no transmission effect is observed from the US to Hong Kong.

Kenourgios, Samitas, and Paltalidis (2007) propose a new model using multivariate copulas to verify the existence of contagion. They apply an AGDCC approach to analyze the degree of dependence between various stock markets (Brazil, Russia, India, China, the US and Britain). They show that there is a strong dependence between markets in periods of crisis and they check that contagion exists for behavioral reasons and not because of changes in macroeconomic fundamentals. Their results show the existence of dependence between exchanges during the crisis period.

Rahman, Sidek, and Tafri (2009) examine the interaction of macroeconomic variables (money supply, exchange rates, reserves, interest rates, and production index) and the market performance of the conventional capital in Malaysia using the methodlogy of VAR model. They found that there was a cointegrating relationship between market returns of conventional capital and selected macroeconomic variables. They find that the conventional capital market has a strong dynamic interaction with reserves and the index of industrial production.

However, very few studies have focused on investigating the transmission of crises between conventional and Islamic banks.

Nazlioglu, Erdem, and Soytas (2013) examine the risk of transmission between the Dow Jones Islamic Index (DJIM) and the three main conventional global equity markets (the US, Europe and Asia) over a period before, during and after the crisis of 2007. They use a causality test to explore the transmission of risk developed by Hafner and Herwartz (2006) and they use impulse response functions to compare how 
Islamic and conventional stock markets react to temporary shocks in the short term. They find that the variance causality test indicates that while there is no risk transmission among oil and agricultural commodity markets in the pre-crisis period, oil market volatility spills onto agricultural markets with the exception of sugar in the post-crisis period. The impulse response analysis also shows that a shock to oil price volatility is transmitted to agricultural markets only in the post-crisis period. They also show that the dynamics of volatility transmission changes significantly following the food price crisis. Finally, after the crisis, risk transmission emerges as another dimension of the dynamic interrelationships among energy and agricultural markets.

Cihak and Hesse (2008) found that small Islamic banks tend to be financially stronger than smaller commercial banks while large commercial banks are financially stronger than large Islamic banks and that small Islamic banks are stronger than large Islamic banks.

Boumediene and Caby (2013) study the stability of Islamic banks during the subprime crisis. According to their results, they show that the volatility of Islamic banks yields increased during the crisis of 2007. They found two main conclusions: first, Islamic banks had been affected by the crisis and second, they face the same risks as conventional banks. The empirical results show that there are signs of risk transfer between the Islamic equity market and the three main traditional markets, which implies the existence of contagion across global equity markets. The structure of the volatility of these markets is dominated by short-term volatility in the first period and a strong long-term volatility in the second period.

Karim, Kassim, and Arip (2010) study the effect of the US subprime crisis on the integration of Islamic stock markets (Malaysia, Indonesia, the US, UK and Japan) over a period from 2006 to 2008. Their study does not conclusively prove the existence of co-integration between these Islamic stock markets for the two periods before and during the crisis.

Kassab (2013) focuses on the structure of volatility and explores the persistence of volatility in the Islamic Market (DJIM) and the stock market index (S\&P500 index), using the Generalized Autoregressive Conditional Heteroskedasticity (GARCH) model. He shows that the persistence of volatility in both markets is very significant, with the DJIM index less volatile than the conventional index in the long term and less risky in times of crisis.

Additionally, Dewandaru, Masih, Rizvi, Masih, and Alhabshi (2014) study 16 multiple crises and found that the shocks were transmitted by excessive links, while the recent subprime crisis revealed the fundamental basis of contagion. This study focuses primarily on the spread in the Asia-Pacific region. According to their results, Islamic actors are less susceptible to any shock because they have less leverage.

Fakhfekh and Hachicha (2014) study the contagion effect between Islamic and conventional banks during the last subprime crisis. They use a DCCMGARCH model to estimate the conditional dynamic correlations. Their empirical results show that the correlation increases between the quiet period and the crisis period. This implies the existence of a contagion effect.

Rizvi, Shaista, and Alam (2015) study the contagion effect on the Asia Pacific market to the US market over a period from 1996 to 2014. This study primarily tries to capture the effects of major crises worldwide over two decades. They found that the majority of global shocks since 1996 have been transmitted through excessive links to Asia-Pacific, while the recent sub-prime crisis reveals a fundamental base of contagion. For the Islamic market, they show that exposure to attacks is limited because of low leverage, while the least diversified portfolio increases vulnerability to future crises.

The main aim of the paper developed by Hashem and Giudici (2016) is to compare the stability, in terms of systemic risk, of conventional and Islamic banking systems. To this aim, they propose correlation network models for stock market returns based on graphical Gaussian distributions, which allows us to capture the contagion effects that move across countries. They also consider Bayesian graphical models to account for model uncertainty in the measurement of financial systems interconnectedness. Their proposed model is applied to the Middle East and North Africa (MENA) region banking sector, characterized by the presence of both conventional and Islamic banks, for the period from 2007 to the 
beginning of 2014. Their empirical findings show that there are differences in the systemic risk and stability of the two banking systems during crisis times. In addition, the differences are subject to country-specific effects that are amplified during the crisis period.

\section{Methodology}

The main purpose of this study is to investigate empirically the presence of financial contagion effect between Islamic and conventional banks in Malaysia during the period of study from March 31, 2004 to March 18, 2014.

We use the DCC-GARCH model to perform the estimation of financial contagion between conventional and Islamic banks in Malaysia.

First, we base our study on the use of the DCCGARCH approach developed by Engle (2002). We note that the vector comprises the performance (expected returns) of both types of banks. With $r_{t}=$ $\left(r_{1 t} ; r_{2 t}\right)^{\prime}$. A(L)expresses the lag polynomial given by:

$$
A(L) r_{t}=\mu+e_{t}
$$

Where, $\mu$ indicates the vector of expected returns and $e_{t}$ is the vector of error terms.

The model of the Dynamic Conditional Correlation (DCC) is based on the assumption that the conditional returns are normally distributed with zero mean and the matrix of the conditional covariance is $H_{t}=E\left[r_{t} r_{t}^{\prime} \mid I_{t-1}\right]$.

The covariance matrix is measured by the equation:

$$
H_{t}=D_{t} R_{t} D_{t}
$$

With, $\quad D_{t}=\operatorname{diag}\left[\sqrt{h_{1 t}}, \sqrt{h_{2 t}}\right]$ is the diagonal matrix of volatilities temporal standard deviations from the univariate estimate of GARCH $(1,1)$. The DCC specification $(1,1)$ can be obtained based on some steps: $(1,1)$ :

First, one identifies the specification GARCH

$$
h_{t}=\alpha_{0}+\alpha_{1} \varepsilon_{t-1}^{2}+\beta_{1} h_{t-1}
$$

Where, $\alpha_{0}, \alpha_{1}$ and $\beta_{1}$ are parameters to be estimated.
The conditional correlation matrix $R_{t}$ standardized distributions $\varepsilon_{t}$ is given by:

$$
R_{t}=\left[\begin{array}{cc}
1 & q_{12 t} \\
q_{21 t} & 1
\end{array}\right]
$$

With, $\varepsilon_{t}=D_{t}^{-1} r_{t}$.

The matrix $R_{t}$ is expressed as follows:

$$
R_{t}=Q_{t}^{*-1} Q_{t} Q_{t}^{*-1}
$$

Where, $\mathrm{Q}_{\mathrm{t}}$ is the temporal conditional volatility matrix $\varepsilon_{t}$ and $Q_{t}^{*-1}$ is the inverse of the diagonal matrix $Q_{t}$. Note that $Q_{t}^{*-1}$ is:

$$
Q_{t}^{*-1}=\left[\begin{array}{cc}
1 / \sqrt{q_{11 t}} & 0 \\
0 & 1 / \sqrt{q_{22 t}}
\end{array}\right]
$$

Thus, the DCC $(1,1)$ is given by the equation:

$$
Q_{t}=\omega+\alpha \varepsilon_{t-1} \varepsilon_{t-1}^{\prime}+\beta Q_{t-1}
$$

Where, $\omega=(1-\alpha-\beta) \bar{Q}$, with $\bar{Q}$ being the covariance matrix unconditional standardized distributions, while $\varepsilon_{t} . \omega, \alpha$, and $\beta$ are parameters to be estimated.

Finally, the dynamic conditional correlation (DCC) is given by:

$$
\rho_{12 t}=\frac{q_{12 t}}{\sqrt{q_{11 t} q_{22 t}}}
$$

According to Engle (2002), the maximum likelihood estimator of the DCC is:

$$
L=-\frac{1}{2} \sum_{t=1}^{T}\left(k \log (2 \pi)+2 \log \left(\left|D_{t}\right|\right)+\log \left(\left|R_{t}\right|\right)+\varepsilon_{t}^{\prime} R_{t}^{-1} \varepsilon_{t}\right)
$$

The maximum likelihood estimator of the dynamic conditional correlation indicates the level of correlation between Islamic and conventional banks which can explain the phenomenon of financial contagion in Malaysia. 


\section{Data}

The main objective of this paper is to verify the presence of financial contagion between Islamic and conventional banks in Malaysia. To do so, we employ the DCC-GARCH model to assess the conditional dynamic correlation which is used to capture financial contagion.

The development of Islamic finance in Malaysia has been relatively late, but it has been particularly rapid since the early 2000s. Islamic finance did not appear in Malaysia until 1983 when the government enacted the Islamic Banking Act, which allowed the creation of Islamic banks, in-line with the funds created in the 1960s to allow the Malays to save for their pilgrimage to Makkah. An initial period, from 1983 to 1993 , was considered a period of experimentation. Only one bank, Bank Islam Malaysia Berhad, was created by the government with a 10year maturity to establish itself in the local banking landscape. The success of this experiment brought
Malaysia into a phase of rapid development of national Islamic finance.

Thus, Malaysia, by solving the difficulties inherent in the Islamic finance market, has largely contributed to the development of specific financial products. In addition to the financial instruments created by the State or the Central Bank, Malaysia has become the world leader in the Islamic bond market, or suku $\bar{u}$, with $74 \%$ of global issues in 2012 (ahead of Saudi Arabia with 8\%), and $70.5 \%$ for the first 8 months of 2013 (10.3\% for Saudi Arabia).

We utilize a sample composed of 1 Islamic bank and 8 conventional banks during the period of study from March 31, 2004 to March 18, 2014. We choose these banks because they represent $90 \%$ of the total market capitalization of banks listed on the stock exchange of Malaysia. The list of banks selected is summarized in Table 1.

Table (1) List of Banks

\begin{tabular}{|l|c|c|}
\hline Name of bank & Code & Nature \\
\hline BIMB Holding & IB & Islamic \\
\hline Affin Holding Berhad & CB1 & Conventional \\
\hline Alliance Financial Group & CB2 & Conventional \\
\hline Malayan Banking MAY Bank & CB3 & Conventional \\
\hline CIMB Group & CB4 & Conventional \\
\hline Hong Leong Bank & CB5 & Conventional \\
\hline Hong Leong Financial Group & CB6 & Conventional \\
\hline Public Bank & CB7 & Conventional \\
\hline RHB Capital & CB8 & Conventional \\
\hline
\end{tabular}

\section{Empirical results}

In Table 2, we present the descriptive statistics of dynamic conditional correlations between the Islamic and conventional banks in Malaysia. We can remark that on average the dyna-mic conditional correlation between Islamic and conventional banks is low. However, we can observe that the DCC has a significant level of negative or positive sign between IB and CB1 only.

The high level, positive or negative, can explain the dynamic conditional correlation between Islamic and conventional banks in which we can observe a high level of contagion. However, a low level, positive or negative, can identify little dynamic depen- dence between Islamic and conventional banks, namely, a low level of contagion. So, we can confirm that the level of dynamic conditional correlation can explain the phenomenon of financial contagion between Islamic and conventional banks in Malaysia.

We notice that on average the dynamic conditional correlation between Islamic and conventional banks is low. The risk level of the DCC between different Islamic and conventional banks in Malaysia is between $0.2 \%$ and $30 \%$. According to the two coefficients of asymmetry (skewness) and leptokurtic (kurtosis), the various variables used in this study are characterized by non-normal distributions. As for the 
skewness, this reflects that the DCC between Islamic and conventional banks is skewed to the left and that it is far from being symmetric for all variables except the DCC between BIMB Holding and Public Bank, which is skewed to the right. Additionally, the kurtosis statistic shows the leptokurtic feature of the series and shows the existence of a high peak or fat tail in the volatilities of all variables.
Similarly, the positive estimate of the Jarque-Bera statistic signifies that we reject the null hypothesis of normal distribution of the variables used in our study. In addition, the high value of the Jarque-Bera statistic reflects that the series is not normally distributed.

Table (2) Descriptive statistics of the DCC between Islamic and conventional banks in Malaysia

\begin{tabular}{|c|c|c|c|c|}
\hline & (IB, CB1) & (IB, CB2) & (IB, CB3) & (IB, CB4) \\
\hline Mean & 0.013683 & -0.000780 & -0.001062 & -0.001035 \\
\hline Median & 0.018045 & $2.60 \mathrm{E}-05$ & $-4.45 \mathrm{E}-05$ & $-2.15 \mathrm{E}-05$ \\
\hline Maximum & 0.991025 & 0.044898 & 0.036134 & 0.035538 \\
\hline Minimum & -0.989176 & -0.163511 & -0.161309 & -0.161571 \\
\hline Std. Dev. & 0.311143 & 0.012393 & 0.012173 & 0.012105 \\
\hline Skewness & -0.014032 & -8.378879 & -8.899936 & -8.995463 \\
\hline Kurtosis & 3.953722 & 90.98183 & 96.12482 & 98.08057 \\
\hline Jarque-Bera & $97.37200^{*}$ & $857979.6^{*}$ & $961455.7^{*}$ & 1001557.* \\
\hline Probability & 0.000000 & 0.000000 & 0.000000 & 0.000000 \\
\hline \multirow[t]{2}{*}{ Observations } & 2567 & 2567 & 2567 & 2567 \\
\hline & (IB, CB5) & (IB, CB6) & (IB, CB7) & $(\mathrm{IB}, \mathrm{CB8})$ \\
\hline Mean & -0.001102 & -0.000956 & -0.000127 & $1.37 \mathrm{E}-05$ \\
\hline Median & $-3.58 \mathrm{E}-05$ & 7.94E-07 & $-4.41 \mathrm{E}-05$ & $-2.75 \mathrm{E}-06$ \\
\hline Maximum & 0.036574 & 0.036192 & 0.063948 & 0.032411 \\
\hline Minimum & -0.161464 & -0.161931 & -0.030497 & -0.048379 \\
\hline Std. Dev. & 0.012264 & 0.012214 & 0.003462 & 0.002566 \\
\hline Skewness & -8.792085 & -8.916232 & 6.661302 & -0.956504 \\
\hline Kurtosis & 94.29194 & 96.16466 & 160.4881 & 128.7161 \\
\hline Jarque-Bera & $924486.0^{*}$ & $962373.8^{*}$ & 2671819.* & 1690819.* \\
\hline Probability & 0.000000 & 0.000000 & 0.000000 & 0.000000 \\
\hline Observations & 2567 & 2567 & 2567 & 2567 \\
\hline
\end{tabular}

$(*),(* *)$, and $(* * *)$ are significant at a level of $1 \%, 5 \%$, and $10 \%$, respectively.

According to Figure 1, we can remark that the dynamic conditional correlation between BIMB Holding (Islamic bank) and other conventional banks in Malaysia attains its peak especially in 2008 after the propagation of the subprime crisis of 2007 and in the debut of the financial crisis of 2008. Also, we find that this DCC is high between BIMB Holding and Affin Holding Berhad which implies that these two banks have a dynamic dependence on their return volatilities. However, BIMB Holding (Islamic bank) and Alliance Financial Group, Malayan Banking MAY Bank, CIMB Group, Hong Leong Bank, Hong Leong Financial Group and RHB Capital (Conventional banks) have a negative and low DCC. This result implies that the risk transmission between Islamic and conventional banks is not important.
Additionally, the DCC between BIMB Holding and Public Bank is positive and low which implies that the financial contagion between these two banks is not important.

In Table 3, we estimate the DCC-GARCH $(1,1)$ between conventional and Islamic banks in Malaysia. We can see that the dynamic conditional correlation estimated between conventional and Islamic banks is low for some and strong for others with a negative or positive sign. We show that the level of DCC can explain the phenomenon of financial contagion between Islamic and conventional banks in Malaysia. Thereafter, we can corroborate the continuation of a financial contagion on the Malaysia banking market for the study period used in our research. 
Figure (1) The dynamic conditional correlation between IB and other conventional banks in Malaysia

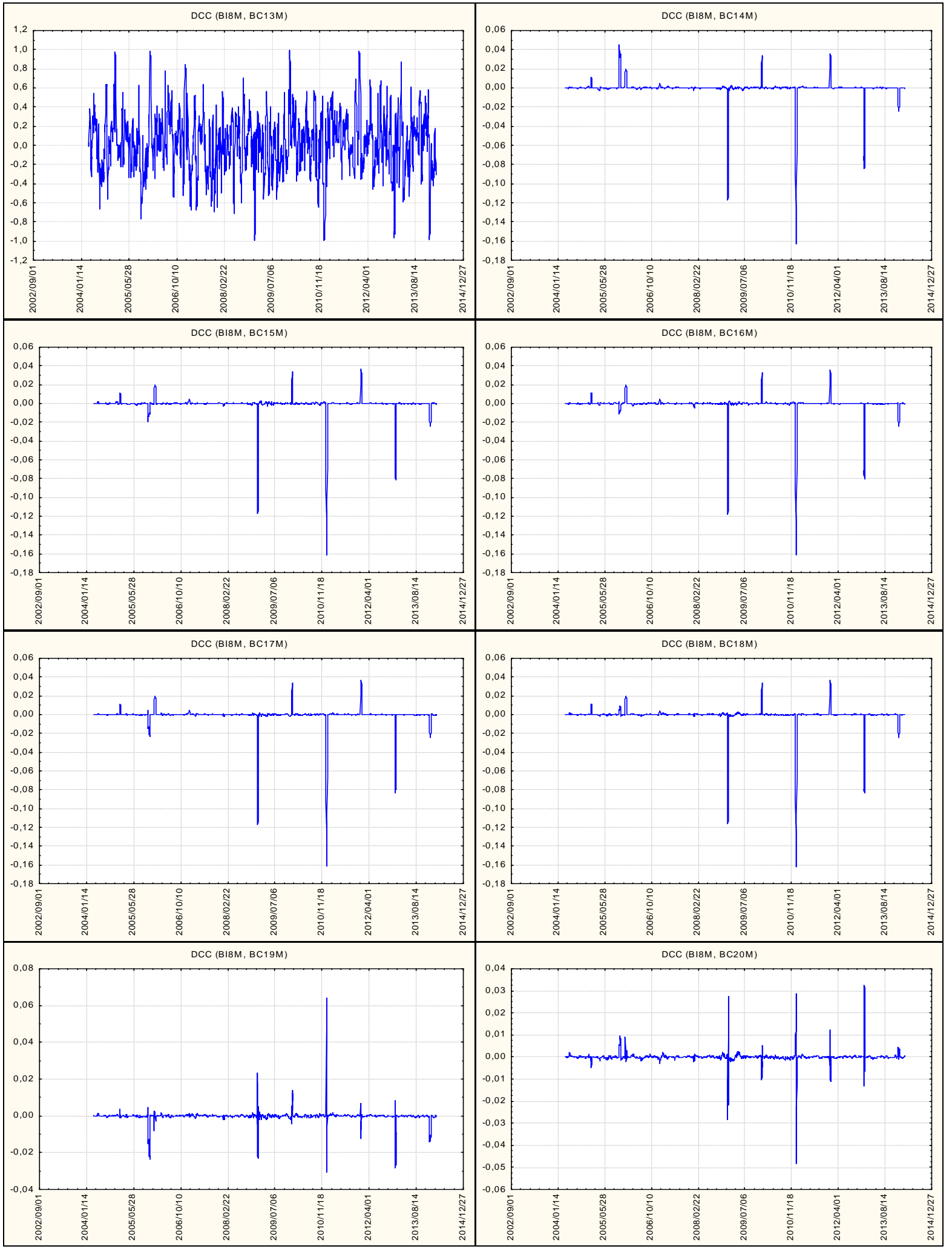


Additionally, the results of the DCC-GARCH model demonstrate that the crisis has not only affected the stock markets but also emerging financial markets. The financial crisis of 2008 has to a certain extent disrupted the syndicated loan markets. In the second half of 2008, interbank rates across the Asian countries rose especially in Malaysia.

After we investigate the effect of the crisis on the stock markets of Malaysia, it may be useful to consider its effect on financial institutions and its financial market. As is the case anywhere else in the world, financial institutions in Malaysia have been affected by the financial crisis via several channels: (i) direct exposure to the U.S. housing market, real estate products or CDOs (Collateralized Debt Obligations); (ii) exposure to institutions (both as shareholders and creditors) that have direct exposure to the U.S. housing market; and (iii) the effect of the crisis on the liquidity needs of the financial institutions in Malaysia.

With the objective of becoming a global hub of Islamic finance, Malaysia has developed a favorable environment for its development: a regulatory framework, specific tools, and high-level training institutions.

Also, if we compare them to their conventional counterparts, Islamic banks have made a radical change in their relationship to depositors. Indeed, this relationship is no longer a classical relationship based on loans and interest payments, but rather a relationship where the bank acts as an investment agent and ensures the participation of depositors, investors and entrepreneurs by distributing remuneration and profits according to the principle of sharing of losses and profits.

Lawyers consider that taking advantage of an intermediary role is lawful and acceptable. To fulfill this role, Islamic financial institutions open investment accounts based on the mudārabah contract (a partnership between investors and client entrepreneurs) to client-depositors; the two parties agree on the distribution of the profit at the beginning of the contract.

Table (3) Estimate of DCC and contagion

\begin{tabular}{|l|c|c|}
\hline & DCC & t-statistic (DCC) \\
\hline (BI, BC1) & 0.5899042 & $(26.58)^{*}$ \\
\hline (BI, BC2) & -0.0904121 & $(1.71)^{* * *}$ \\
\hline (BI, BC3) & 0.0632071 & $(1.09)$ \\
\hline (BI, BC4) & 0.0370018 & $(20.46)^{*}$ \\
\hline (BI, BC5) & 0.6758167 & $(-1148.38)^{*}$ \\
\hline (BI, BC6) & -0.9875176 & $(987.52)^{*}$ \\
\hline (BI, BC7) & 0.998536 & $(1425.87)^{*}$ \\
\hline (BI, BC8) & 0.9733255 & \\
\hline
\end{tabular}

$(*),(* *)$, and $(* * *)$ are significant at a level of $1 \%, 5 \%$, and $10 \%$, respectively.

\section{Conclusion}

This paper's aim is to investigate empirically the presence of the financial contagion effect between Islamic and conventional banks in the financial market of Malaysia. Econometrically, we utilize the DCCGARCH model to quantify financial contagion.

From the empirical findings, we conclude that the dynamic conditional correlation estimated between conventional and Islamic banks in Malaysia is low for some and strong for others with a negative or positive sign. The high level, positive or negative, can explain the dynamic dependence between Islamic and conventional banks in which we can observe a high level of contagion. However, the low level, positive or negative, can clarify the little dynamic dependence between Islamic and other conventional banks where we observe a low level of contagion. So, in certain cases we can confirm that the level of dynamic conditional correlation can explain the phenomenon of financial contagion between Islamic and conventional banks in Malaysia. 
It is also to be noted that Islamic finance does not exist in a separate financial environment, but it is facing an environment of interdependence with the international financial market that experiences more and more repetitive and unpredictable shocks and requires measures to mitigate the effects of shocks on the real sector of the economy.

Based on the results of this study, we recommend that operators of Islamic financial systems should try

\section{References}

Aziz, Z. A. (2008, November). Enhancing the Resilience and Stability of the Islamic Financial System. Keynote address at the Islamic Financial Services Board and Institute of International Finance Conference, Kuala Lumpur, 20 November, 2008. Retrieved from: www.bis.org/review/r081126c.pdf

Baba, Y., Engle, R. F., Kraft, D. F., \& Kroner, K. F. (1991). Multivariate Simultaneous Generalized ARCH (Unpublished MS thesis). Department of Economics, University of California, San Diego.

Bekaert, G., \& Harvey, C. R. (1997). Emerging equity market volatility. Journal of Financial Economics, 43(1), 29-77.

Betz, F., Oprică, S., Peltonen, T. A., \& Sarlin, P. (2014). Predicting Distress in European Banks. Journal of Banking \& Finance, 45(C), 225-241.

Boumediene, A., \& Caby, J. (2013). The financial volatility of Islamic banks during the subprime crisis. Bankers, Markets and Investors, 126, 30-39.

Bourkhis, K., \& Nabi, M. S. (2013). Islamic and conventional banks' soundness during the 2007-2008 financial crisis. Review of Financial Economics, 22(2), 68-77.

Cihak, M., \& Hesse, H. (2008). Islamic Banks and Financial Stability: An Empirical Analysis (IMF Working Paper No. WP/08/16). Retrieved from:

https://www.imf.org/external/pubs/ft/wp/2008/wp0816.pdf

Dewandaru, G., Rizvi, S. A., Masih, R., Masih, M., \& Alhabshi, S. O. (2014). Stock market co-movements: Islamic versus conventional equity indices with multitimescales analysis. Economic Systems, 38(4), 553-571.

Eichengreen, B., Rose, A. K., \& Wyplosz, C. (1996). Contagious Currency Crises (NBER Working Paper No. 5681). Retrieved from: http://www.nber.org/ papers/w5681.pdf

Engle, R. (2002). Dynamic conditional correlation: a simple class of multivariate generalized autoregressive conditional heteroskedasticity models. Journal of Business and Economic Statistics, 20(3), 339-350. to adopt prudent risk management practices and Sharīah-compliant hedging mechanisms to defend the stability of the Islamic financial markets in times of economic and financial crisis. Several approaches have been developed in this direction, such as macroprudential policy which aims to limit systemic risks and to avoid exposure of the real sector of the economy to the risks and devastating disruptions of financial crises.

Fakhfekh, M., \& Hachicha, N. (2014). Return volatilities and contagion transmission between Islamic and conventional banks throughout the subprime crisis: evidence from the DCC-MGARCH model. International Journal of Managerial and Financial Accounting, 6(2), 133-145.

Hafner, C. M., \& Herwartz, H. (2006). A Lagrange multiplier test for causality in variance. Economics letters, 93(1), 137-141.

Hamao, Y., Masulis, R. W., \& Ng, V. (1990). Correlations in Price Changes and Volatility across International Stock Markets. The Review of Financial Studies, 3(2), 281-307.

Hasan, M., \& Dridi, J. (2010). The Effects of the Global Crisis on Islamic and Conventional Banks: A Comparative Study (IMF Working Paper No. WP/10/201). Retrieved from: https://www.imf.org/ external/pubs/ft/wp/2010/wp10201.pdf.

Hashem, S. Q., \& Giudici, P. (2016). Systemic Risk of Conventional and Islamic Banks: Comparison with Graphical Network Models. Applied Mathematics, 7, 2079-2096.

Karim, B. A., Kassim, N. A., \& Arip, M. A. (2010). The subprime crisis and Islamic Stock Markets integration. International Journal of Islamic and Middle Eastern Finance and Management, 3(4), 363-371.

Karolyi, G. A., \& Stulz, R. M. (1996). Why do Markets Move Together? An Investigation of U.S.-Japan Stock Return Comovements. The Journal of Finance, 51(3), 951-986.

Kassab, S. (2013). Modeling volatility stock market using the ARCH and GARCH models: comparative study index (SP Sharia VS SP 500). European Journal of Banking and Finance, 10, 72-77.

Kenourgios, D., Samitas, A., \& Paltalidis, N. (2007, June). Financial Crises and Contagion: Evidence for BRIC Stock Markets. Paper presented at the European Financial Management Association Annual Conference, 27th-30th June 2007, Vienna, Austria. 
King, M., \& Wadhwani, S. (1990). Transmission of Volatility between Stock Markets. The Review of Financial Studies, 3(1), pp. 5-33.

Lee, S. B., \& Kim, K. J. (1993). Does the October 1987 Crash Strengthen the Co-Movements Among National Stock Markets? Review of Financial Economics, 3(1), 89-102.

Nabi, M. S. (2012). Dual Banking and Financial Contagion. Islamic Economic Studies, 20(2), 29-54.

Nazlioglu, S., Erdem, C., \& Soytas, U. (2013). Volatility spillover between oil and agricultural commodity markets. Energy Economics, 36(C), 658-665.
Ng, A. (2000). Volatility Spillover Effects from Japan and the US to the Pacific-Basin. Journal of International Money and Finance, 19(2), 207-233.

Rahman, A. A., Sidek, N. Z. M., \& Tafri, F. H. (2009). Macroeconomic determinants of Malaysian Stock market. African Journal of Business Management, 3(3), 95-106.

Rizvi, S., Shaista, A., \& Alam, N. (2015). Crises and Contagion in Asia Pacific - Islamic v/s Conventional Markets. Pacific-Basin Finance Journal, 34(C), 315326.

Tai, C.-S. (2004). Can bank be a source of contagion during the 1997 Asian crisis? Journal of Banking and Finance, 28(2), 399-421.

Monia Ben Ltaifa is a doctor in Finance at the Faculty of Economic Sciences and Management of Sfax, University of Sfax (Tunisia). She is one of the reviewer members in Cogent Business and Management. Her research interests include Islamic finance, financial markets, financial economics, risk management and capital markets and institutions. She has taught as a teaching assistant for four years. She has published papers in the Journal of Business Studies Quarterly, International Journal of Academic Research in Accounting, Finance and Management Sciences, in the International Journal of Financial Innovation in Banking (Inderscience Publishers) and in International Journal of Management and Enterprise Development (Inderscience Publishers)

E-mail: monia_mbl@yahoo.fr

Walid Khoufi is a Professor of Finance at the Faculty of Economic Sciences and Management of Sfax, Department of Finance, University of Sfax, Tunisia. His research interests are pricing, credit risk, financial markets, and Islamic finance.

E-mail: walid.khoufi@yahoo.fr 


\title{
العدوى بين البنوك الإسلامية والتقليدية في ماليزيا: تحقيق تجريبي بواسطة نموذج (DCC-GARCH)
}

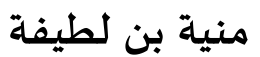 \\ كلية العلوم الاقتصادية والتصرف بصفاقس، جامعة صفاقس، تونس منسية \\ وليد خوفي \\ معهد الدراسات العليا التحارية بصفاقس، جامعة صفاقس، تونس
}

المستخلص. يهدف هذا البحث إلى مقارنة الاستقرار من حيث العدوى بين البنوك الإسلامية

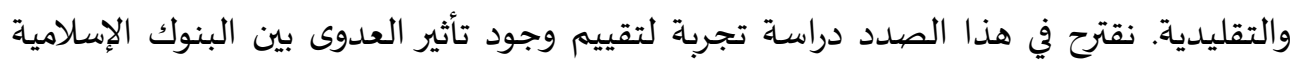

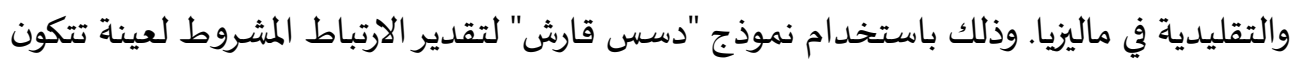

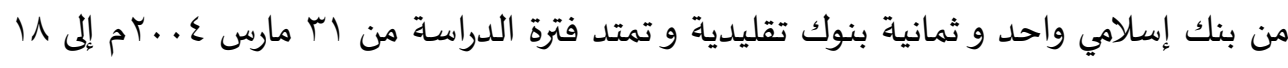

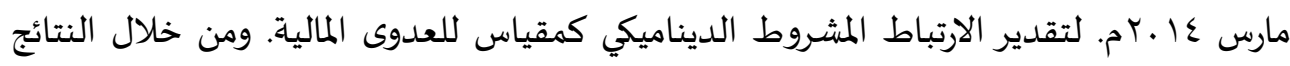

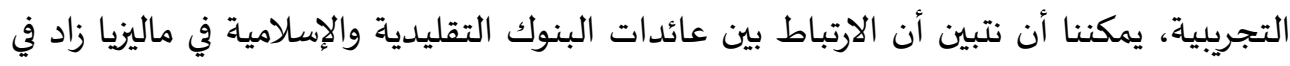

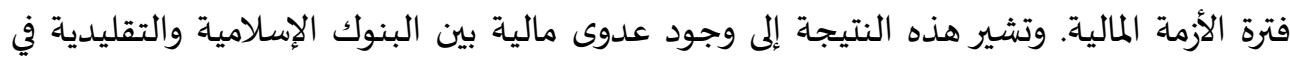

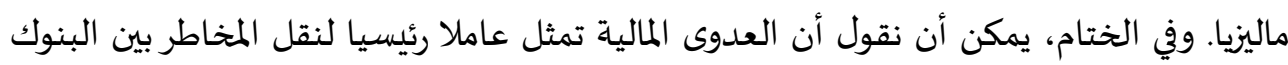
الإسلامية و التقليدية. 